\title{
FAKTOR YANG MEMPENGARUHI KEAKTIFAN BELAJAR PESERTA DIDIK KELAS III SD
}

\section{FACTORS INFLUENCING STUDY ACTIVENESS OF STUDENTS STUDYING IN GRADE III}

\author{
Feni Farida Payon**1, Dyka Andrian ${ }^{2}$, Sasi Mardikarini ${ }^{3}$ \\ ${ }^{1,2,3}$ Program Studi Penddikan Guru Sekolah Dasar, Fakultas Keguruan dan Ilmu Pendidikan, Universitas \\ Doktor Nugroho Magetan, Indonesia \\ e-mail:*11 feni.payon@gmail.com, ${ }^{2}$ dykaandrian@udn.ac.id, ${ }^{3}$ sasimardikarini@udn.ac.id
}

\begin{abstract}
ABSTRAK
Pembelajaran yang baik adalah pembelajaran yang dapat mengaktifkan peserta didik. Tujuan dari penelitian ini adalah untuk mengetahui apa saja faktor-faktor yang dapat memengaruhi keaktifan belajar peserta didik pada muatan IPA di kelas III Sekolah Dasar. Jenis penelitian yang digunakan dalam penelitian ini adalah penelitian kualitatif. Subjek penelitian dalam penelitian ini adalah guru kelas III dan kepala sekolah selaku pembina. Objek dari penelitian ini adalah peserta didik kelas III SDN Ngujung 2 Maospati. Teknik pengumpulan yang digunakan dalam penelitian ini adalah observasi dan wawancara. Teknik analisis data yang digunakan dalam penelitian ini adalah reduksi data, penyajian data dan penarikan kesimpulan. Hasil penelitian ini berupa faktor-faktor internal yang memengaruhi keaktifan belajar peserta didik kelas III Sekolah Dasar terdiri dari faktor internal dan eksternal. Faktor-faktor internal yang memengaruhi keaktifan belajar yaitu faktor fisiologis berupa keadaan fisik (panca indra), faktor psikologis berupa perhatian, tanggapan, serta ingatan menjadi faktor pendukung keaktifan belajar peserta didik. Sedangkan keadaan jasmani menjadi faktor penghambat keaktifan belajar peserta didik. Faktor-faktor eksternal yang memengaruhi keaktifan belajar peserta didik kelas III adalah faktor nonsosial yaitu tempat dan fasilitas serta faktor sosial yaitu guru dan teman sebaya. Tempat, fasilitas, dan guru menjadi faktor pendukung keaktifan belajar peserta didik. Sedangkan teman sebaya menjadi faktor yang dapat mengganggu keaktifan belajar peserta didik.
\end{abstract}

Kata kunci: Keaktifan Belajar, peserta didik, IPA

\begin{abstract}
A good education is one that is able to make students active. The aim of this study is to understand factors influencing study activeness of students studying biology in grade III of elementary school. This is a qualitative research type. The teachers teaching grade III and school's headmaster (as an advisor) are the subjects of this study. And the students of grade III of SDN Ngujung 2 Maospati are the objects of this study. In data collection observation and interview were used. Afterward, data reduction, data presentation, and conclusion drawing were used as data analysis techniques. We obtained internal and external factors influencing study activeness of students of grade III. Physiological factor such as the five senses, psychological factor such as attention, feedback, and supporting factor such as memory affect study activeness and are categorized as internal factors while, physical constitution hinders study activeness. External factors affecting study activeness are teachers and friends. Place and facilities become supporting factor in study activeness while, friends can hinder study activeness.
\end{abstract}

Keywords: Study Activeness, Students, Biology 


\section{PENDAHULUAN}

Belajar adalah hal yang semestinya dilakukan agar dapat berkembang dan beradaptasi dengan lingkungan. Belajar di sekolah melibatkan hubungan erat yang bersifat dinamis antara guru, peserta didik, dan bahan ajar. Guru bertanggungjawab bukan sekedar mentransfer materi, tetapi juga harus mampu memberikan motivasi kepada peserta didik, salah satunya agar peserta didik dapat aktif dalam kegiatan belajar. Keaktifan peserta didik ini tentu akan mendukung kegiatan belajar mengajar di sekolah menjadi lebih optimal.

Sementara itu bahan ajar adalah perangkat yang digunakan oleh guru untuk mendukung kegiatan pembelajaran di kelas. Bahan ajar yang dimaksud meliputi konten isi materi [1]. Konten materi tentu saja dipilih dengan mengacu pada kompetensi yang diharapkan berkembang. Disamping itu, bahan ajar yang dikembangkan juga semestinya disesuaikan dengan tahap perkembangan dan kebutuhan peserta didik. Ketepatan dalam penyusunan bahan ajar akan menjadikan peserta didik lebih aktif lagi dalam kegiatan pembelajarann.

Keaktifan belajar peserta didik dapat terjadi apabila adanya faktor-faktor yang mendukung di dalamnya. Faktor-faktor belajar meliputi peserta didik, guru, materi, tempat, waktu, dan fasilitas [2]. Peserta didik yang aktif dapat terbentuk apabila guru memperbaiki keterlibatan peserta didik melalui peningkatan persepsi peserta didik. Oleh sebab itu, penting bagi guru untuk memilih model pembelajaran yang menyenangkan dan dapat melibatkan seluruh peserta didik [3]. Pemilihan gaya belajar juga harus jelas dan tepat sehingga dapat memacu minat peserta didik untuk terlibat dalam kegiatan pembelajaran [2]. Disamping itu, pembelajaran yang dilakukan juga harus jelas dan tepat sesuai tujuan yang hendak dicapai dan mengusahakan agar pembelajaran mengacu pada minat peserta didik [4]. Oleh sebab itu, guru memegang peran yang cukup besar dalam membangkitkan keaktifan belajar peserta didik, melalui perancanan pembelajaran yang tepat.

Keaktifan belajar akan membawa peserta didik menjadi lebih baik lagi selama mengikuti proses pembelajaran yang mencakup aspek kognitif, afektif, dan psikomotor [5]. Faktor yang memengaruhi keaktifan belajar peserta didik dapat digolongkan menjadi tiga macam, yaitu faktor internal (faktor dari dalam peserta didik), faktor eksternal (faktor dari luar peserta didik), dan faktor pendekatan belajar (approach to learning) [6]. Keaktifan peserta didik selama proses belajar mengajar merupakan salah satu indikator adanya keinginan atau aktivitas peserta didik untuk belajar. Peserta didik dikatakan memiliki keaktifan apabila ditemukan ciri-ciri perilaku seperti sering bertanya, mengerjakan tugas dengan senang, berani maju tanpa disuruh, mencari cara sendiri untuk memahami materi, mencoba sendiri, dan mengkomunikasikan pemikirannya [7].

Berdasarkan pengamatan selama bulan September-Desember 2019, peserta didik kelas III di SDN Ngujsung 2 tahun ajaran 2019/2020 banyak yang masih terlihat kurang aktif dalam kegiatan pembelajaran. Hal ini terlihat dari kurang konsentrasinya peserta didik pada materi pelajaran yang sedang diberikan oleh guru. Khususnya dalam pembelajaran IPA, beberapa peserta didik terlihat mengajak peserta didik lain untuk bermain dan berbincang-bincang pada saat guru sedang menerangkan pembelajaran di depan kelas. Selain itu, saat mereka ditanya oleh guru atau diberi kesempatan untuk bertanya, peserta didik terlihat kurang aktif. Hanya terlihat dua peserta didik saja yang mau bertanya saat pelajaran berlangsung. Dan apabila peserta didik diberi pertanyaan oleh guru, sebagian besar tidak dapat langsung menjawab, namun bertanya pada teman sebelahnya terlebih dahulu atau membuka buku yang ada di mejanya. Bahkan beberapa peserta didik tidak bisa menjawab walaupun sudah dipancing oleh gurunya.

Antusias belajar peserta didik cukup lemah di kelas tersebut. Ada peserta didik yang sering ijin ke belakang hanya untuk sekedar keluar kelas dan melihat suasana diluar kelas. Beberapa peserta didik juga tertunduk lesu di kelas. Berdasarkan pengamatan dari sisi guru, selama observasi berlangsung, guru tidak menggunakan media pembelajaran yang menarik. Guru hanya menggunakan buku cetak dari pemerintah dan pembelajaran dengan ceramah dan tanya jawab. Berdasarkan uraian tersebut maka peneliti insgin melakukan penelitian mengenai faktor- 
faktor apa saja yang dapat mempengaruhi keaktifan belajar peserta didik di SDN Ngujung 2, Kecamatan Maospati, Kabupaten Magetan. Tujuan dari peneliti ini adalah Untuk mengetahui apa saja faktor-faktor dapat memengaruhi keaktifan belajar peserta didik pada muatan IPA di kelas III SD.

\section{METODE PENELITIAN}

Penelitian dilaksanakan di kelas III SDN Ngujung 2. Pendekatan dalam penelitian ini menggunakan pendekatan kualitatif. Penelitian tersebut, bermaksud untuk memahami fenomena tentang yang dialami oleh subjek penelitian secara holistik yang selanjutnya dideskripsi dalam bentuk kata-kata dan bahasa yang ilmiah [8]. Jenis penelitian yang digunakan oleh peneliti dalam penelitian ini adalah jenis penelitian deskriptif kualitatif. Penelitian ini dimaksudkan untuk mendeskripsikan segala sesuatu yang berkaitan dengan kegiatan pembelajaran di kelas dan faktorfaktor yang memengaruhi keaktifan belajar peserta didik kelas III di SDN Ngujung 2.

Dalam penelitian ini, yang akan diamati adalah peserta didik kelas III SDN Ngujung 2 dengan berbagai karakteristiknya. Subjek dalam penelitian ini adalah peserta didik kelas III SDN Ngujung 2. Adapun subjek lain yang dijadikan sebagai sumber informan adalah guru kelas III dan kepala sekolah selaku pembina. Objek dalam penelitian ini adalah kegiatan pembelajaran dan faktor-faktor yang memengaruhi keaktifan belajar peserta didik kelas III SDN Ngujung.

Sumber data utama dalam penelitian kualitatif ialah peserta didik, dan tindakan selebihnya adalah data tambahan seperti dokumen dan lain-lain. Yang menjadi data primer dalam penelitian ini adalah hasil observasi, wawancara, data tertulis berdasarkan hasil wawancara dengan informan mengenai masalah yang diteliti, gambar atau foto kegiatan pembelajaran dan wawancara. Data sekunder dalam penelitian ini merupakan data yang diperoleh dari buku atau telaah gambar dan sumber referensi lain yang berkaitan dengan penelitian yang akan dilakukan oleh peneliti.

Pada penelitian ini teknik pengumpulan data yang digunakan adalah observasi dan wawancara. Dalam penelitian ini, jenis observasi yang digunakan adalah observasi non partisipasi di mana peneliti tidak ikut serta dalam kegiatan yang diamati. Peneliti berada di tempat kegiatan berlangsung akan tetapi tidak terlibat. Peneliti hanya mengamati kondisi atau kegiatan yang ada. Peneliti mencatat, menganalisis, dan membuat kesimpulan mengenai kegiatan pembelajaran dan faktor-faktor yang memengaruhi keaktifan belajar peserta didik kelas III SDN Ngujung 2.

Pada penelitian ini menggunakan teknik wawancara semi terstruktur (semistructure interview). Wawancara ini bertujuan untuk menemukan permasalahan secara lebih terbuka, di mana pihak yang diajak wawancara diminta pendapat dan idenya. Prosedur Penelitian yaitu perencanaan, pelaksanaan dan Observasi. Ada empat kriteria yang digunakan dalam menguji keabsahan data suatu penelitian, yaitu derajat kepercayaan, keteralihan, kebergantungan, dan kepastian. Pada penelitian ini, peneliti menggunakan uji kredibilitas dalam uji keabsahan data [8].

Pengujian kredibilitasnya menggunakan triangulasi. Triangulasi yang digunakan peneliti adalah triangulasi sumber dan triangulasi teknik. Analisis data kualitatif adalah bersifat induktif, yaitu suatu analisis berdasarkan data yang diperoleh, selanjutnya dikembangkan pola hubungan tertentu atau menjadi hipotesis [9]. Adapun aktivitas dalam analisis data yaitu reduksi data, penyajian data, penarikan kesimpulan.

\section{HASIL DAN PEMBAHASAN}

\section{Hasil Penelitian}

\section{Faktor Internal Peserta didik yang Mempengaruhi Keaktifan Belajar}

Faktor internal yang memengaruhi keaktifan belajar peserta didik kelas III SDN Ngujung 2 tahun ajaran 2019/2020 dapat dikelompokkan menjadi faktor fisiologis dan faktor 
psikologis. Faktor fisiologis meliputi keadaan fisik (panca indera) dan keadaan jasmani dan faktor psikologis yang meliputi perhatian, tanggapan, dan ingatan.

Di SDN Ngujung 2 khususnya kelas III tidak ditemukan masalah dari sisi faktor fisiologis, artinya tidak ditemukan peserta didik yang mengalami masalah keadaan fisik. Semua peserta didik dalam keadaan normal, dan tidak diffabel. Sedangkan selama proses observasi, pengamat juga tidak menemukan peserta didik yang mengalami masalah dalam keadaan jasmani. Semua peserta didik dalam keadaan sehat yang masuk ke sekolah, berikut juga dengan gurunya. Sehingga dapat dikatakan faktor fisiologis peserta didik sangat mendukung keaktifannya didalam kelas.

Sementara itu dari hasil analisis dalam faktor psikologis peserta didik di SDN Ngujung 2 ditemukan adanya peserta didik yang percaya diri untuk menjawab pertanyaan dari guru, adanya peserta didik yang berani menanggapi jawaban dari peserta didik lain, adanya peserta didik yang berani menyempurnakan jawaban dari peserta didik lain, dan adanya peserta didik yang berani bertanya materi yang belum dipahami. Akan tetapi,tidak semua peserta didik melakukan hal demikian. Artinya keaktifan di kelas tersebut, belum secara optimal terjadi. Masih banyak peserta didik-peserta didik lain yang tidak percaya diri, tidak berani menanggapi, dan tidak mau bertanya.

Terlebih, dari hasil pengamatan yang telah dilakukan, peserta didik menunjukkan ketidakaktifannya dalam kegiatan pembelajaran pada jam-jam tertentu. Diantaranya setelah jam olahraga atau bermain yang menguras energi, peserta didik akan merasa kelelahan, sehingga tidak fokus saat pelajaran berlangsung.

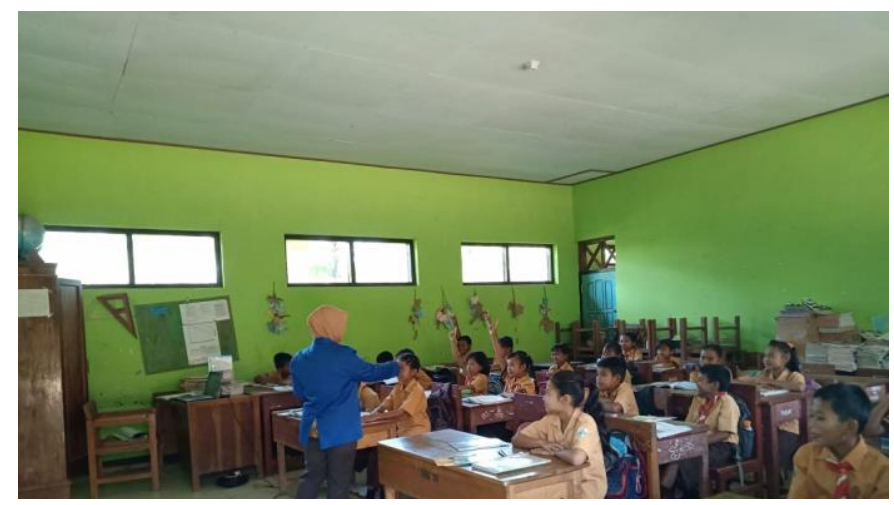

\section{Gambar 1 Kurang Aktifnya Peserta Didik Setelah Jam Istirahat}

Pada Gambar 1 terlihat hanya segelintir peserta didik yang mengangkat tangan, menanggapi dan bertanya terkait materi yang disampaikan. Sementara peserta didik yang lain lebih banyak diam, tetapi tidak fokus pada materi yang disampaikan. Pada kesempatan lain juga beberapa kali dijumpai ada peserta didik yang sering menguap saat pembelajaran, terlebih pada saat pembelajaran yang dilaksanakan siang hari. Dengan demikian, kegiatan peserta didik yang dilakukan sebelum kegiatan belajar mengajar akan sangat mempengaruhi keaktifan peserta didik di kelas.

\section{Faktor-Faktor Eksternal yang Mempengaruhi Keaktifan Belajar Peserta didik}

Berdasarkan hasil penelitian, faktor eksternal yang memengaruhi keaktifan belajar peserta didik kelas III SDN Ngujung 2 tahun ajaran 2019/2020 yaitu faktor non sosial dan faktor sosial. Faktor non sosial terdiri dari tempat dan fasilitas. Sedangkan faktor sosial terdiri dari guru dan teman sebaya.

Pertama, dari faktor non sosial yang meliputi tempat dan fasilitas. Ruang kelas III SDN Ngujung 2 terletak dipinggir jalan perkampungan, sehingga tidak teralalu mengganggu proses pembelajaran. Hal ini karena jarang terdengar suara kendaraan. Peserta didik juga terlihat nyaman dengan tempat duduk yang ditempati untuk belajar. Fasilitas pendukung yang tersedia di SDN Ngujung 2 meliputi berbagai jenis buku. Peserta didik memanfaatkan buku pinjaman dari perpustakaan. Buku pinjaman dari perpustakaan tersebut dipakai secara bersama-sama satu kelas. 
Kedua, faktor sosial dalam hasil observasi ini terlihat dari faktor guru yang selalu memberikan motivasi kepada peserta didik agar mereka belajar sungguh-sungguh. Guru juga tidak bosan-bosan memberikan berbagai nasihat kepada peserta didik. Artinya, guru tidak hanya mentransfer ilmu saja, tetapi juga mendorong peserta didik, khususnya agar selalu aktif dalam mengikuti kegiatan belajar di sekolah.

Teman sebaya juga turut mempengaruhi peserta didik dalam kegiatan pembelajaran di kelas. Pada saat teman sebaya aktif di kelas, mengikuti pelajaran dengan tertib, peserta didik pun akan terpengaruh. Akan tetapi, tidak sedikit teman sebaya yang justru membuat kegiatan pembelajaran di kelas menjadi tidak kondusif, sehingga berdampak pada keaktifan belajar peserta didik.

Berdasarkan hasil pengamatan, ada beberapa peserta didik mencoba mengganggu konsentrasi belajar peserta didik lain yang duduk di belakangnya. Beberapa peserta didik berbicara sendiri ketika pembelajaran berlangsung. Hal ini membuat peserta didik lain kurang dapat konsentrasi pada saat guru menjelaskan materi pelajaran. Berdasarkan hasil pengamatan dan hasil wawancara peserta didik dapat disimpulkan bahwa teman sebaya merupakan faktor yang mempengaruh keaktifan belajar peserta didik.

\section{Pembahasan}

\section{Faktor Internal Peserta didik yang Mempengaruhi Keaktifan Belajar}

Berdasarkan hasil penelitian menunjukkan bahwa faktor internal yang memengaruhi keaktifan belajar peserta didik yaitu faktor fisiologis dan faktor psikologis. Faktor fisiologis meliputi keadaan fisik (panca indera) dan keadaan jasmani. Faktor fisiologis sangat mendukung keaktifan peserta didik dalam belajar, karena dengan memiliki panca indra yang sempurna dan keadaan jasmani yang sehat peserta didik dapat mudah menerima pembelajaran serta dapat aktif di dalam kelas. Selain itu, keadaan fungsi fisiologis terutama fungsi panca indra merupakan salah satu faktor utama belajar, dimana jika panca indra berdungsi baik merupajan syarat belajar dapat berlangsung dengan baik [10].

Selain faktor fisiologis, faktor psikologis juga sangat mendukung keaktifan belajar. Faktor psikologis yang muncul dalam observasi ini meliputi perhatian, tanggapan, dan ingatan. Peserta didik terlihat percaya diri untuk menjawab pertanyaan dari guru, peserta didik yang berani menanggapi jawaban dari peserta didik lain, peserta didik berani menyempurnakan jawaban dari peserta didik lain, dan peserta didik berani bertanya materi yang belum dipahami. Oleh karena itu, tanggapan memainkan peranan penting dalam belajar atau perkembangan anak didik karena itu tanggapan harus dikembangkan dan dikontrol sebaik-baiknya [10].

Faktor internal merupakan faktor yang sangat memiliki pengaruh besar pada keaktifan peserta didik dalam pembelajaran. Faktor ini dapat sangat mendukung, namun kadang kala dapat sangat menghambat proses pembelajaran serta keaktifan peserta didik dalam belajar di kelas. salah satu contoh faktor internal yang dapat menghambat keaktifan belajar adalah adanya peserta didik yang suka mengganggu temannya di dalam pembelajaran baik dengan mengajar bermain atau mengobrol bersama. Hal itu dapat terjadi karena banyak hal seperti pelajaran yang kurang menarik, pelajaran yang dilakukan setelah beraktifitas yang melelahkan seperti olahraga, serta adanya cacat tubuh yang dimiliki oleh peserta didik.

Pelaksanaan penelitian ini ditemukan salah satu kasus bahwa pelajaran tidak berlangsung dengan baik karena peserta didik tidak konsentrasi dalam pembelajaran. beberapa peserta didik bermain sendiri, menguap/mengantuk, merasa kepanasan dalam pembelajaran. hal ini mungkin disebabkan karena pelajaran dilakukan setelah kegiatan olahraga berlangsung dan peserta didik belum merasa cukup waktu untuk beristirahat/makan dan minum. Hal ini karena faktor jasmani yang mempengaruhi kegiatan belajar [11]. Oleh sebab itu, sebisa mungkin, sebelum proses pembelajaran dimulai, kondisi tubuh harus dalam keadaan siap, tidak terlalu lelah, tidak mengantuk, dan sebagainya. 


\section{Faktor-Faktor Eksternal Mempengaruhi Keaktifan Belajar Peserta didik}

Faktor eksternal yang dikelola dengan baik akan sangat mendukung keaktifan belajar peserta didik di dalam pembelajaran. Salah satu contoh faktor eksternal adalah sarana dan prasarana sekolah untuk pembelajaran. Alat pembelajaran merupakan salah satu sarana dan prasarana yang diperlukan peserta didik dalam kegiatan pembelajaran [12]. Termasuk dalam sarana dan prasarana adalah ketersediaan buku dan bahan bacaan yang memadai bagi peserta didik. Ketepatan penggunaan sarana dan prasarana dalam kegiatan belajar, sangat mempengaruhi keaktifan belajar peserta didik.

Selain sarana dan prasarana, letak sekolah juga sangat mendukung keaktifan peserta didik dalam belajar di kelas. Sekolah yang berada jauh dari jalan raya besar atau keramaian akan lebih membuat peserta didik fokus belajar dibandingkan dengan sekolah yang dekat dengan keramaian. Pemanfaatan lingkungan di Sekolah Dasar yang tepat dapat membantu guru dalam menyampaikan materi atau informasi pembelajaran, sehingga dapat menumbuhkan antusias peserta didik yang baik, serta dapat menumbuhkan ide-ide kreatif peserta didik dalam belajarnya [13]. Hal tersebut tentu dapat menjalin hubungan baik antara peserta didik dengan peserta didik maupun peserta didik dengan guru. Dengan demikian, keaktifan belajar diharapkan dapat berkembang dengan optimal pada diri peserta didik.

Keaktifan belajar peserta didik juga dapat dipengaruhi dengan berbagai kegiatan pembelajaran yang dirancang oleh guru. Kegiatan pembelajaran yang inovatif akan membuat peserta diidk menjadi mandiri dan menjangkau kegiatan peserta didik dalam proses belajar dan pembelajaran [14]. Hasil penelitian terdahulu juga menyebutkan bahwa pemilihan model pembelajaran dapat meningkatkan aktifitas belajar peserta didik [15]. Oleh sebab itu, kegiatan pembelajaran perlu dirancang sedemikian rupa agar dapat memacu keaktifan peserta didik.

Lingkungan sosial juga turut mempengaruhi keaktifan belajar peserta didik di kelas. Lingkungan sosial peserta didik di sekolah atau di kelas dapat berpengaruh pada semangat belajar di kelas. Cakupan lingkungan sosial di sekolah meliputi hubungan antara peserta didik dengan guru, dan hubungan antara peserta didik dengan teman sebayanya. Guru perlu merencanakan dan memberikan pendampingan belajar yang tepat agar dapat mendukung keaktifan belajar peserta didik. Hal ini karena pendampingan belajar yang tepat dari guru akan memberikan peluang besar peserta didik untuk mengembangkan potensinya, termasuk keaktifan peserta didik [16]. Dengan kata lain dapat diuraikan bahwa, teman yang pintar dan rajin belajar, akan membuat peserta didik untuk mengikuti temannya untuk belajar.

Teman sebaya selain dapat memberikan pengaruh yang positif seperti yang telah diuraikan sebelumnya juga dapat memberi pengaruh yang negatif. Kehadiran orang pada waktu seseorang sedang belajar, terkadang juga dapat mengganggu belajar [10]. Kehadiran seseorang dalam hal ini adalah teman sekelasnya (teman sebayanya) yang berjalan-jalan atau yang mengajak berbincang-bincang, secara otomatis akan mempengaruhi temannya yang lainnya.

\section{SIMPULAN}

Faktor-faktor internal yang memengaruhi keaktifan belajar peserta didik kelas III SDN Ngujung 2 tahun ajaran 2019/2020 adalah faktor fisiologis dan psikologis. Faktor fisiologis meliputi keadaan fisik (panca indra). Sedangkan faktor psikologis meliputi perhatian, tanggapan, dan ingatan menjadi faktor pendukung keaktifan belajar peserta didik. Kedua faktor tersebut secara umum telah mendukung keaktifan peserta didik. Peserta didik hanya perlu menjaga kondisi, agar fisiknya siap untuk belajar, sehigga tidak kelelahan saat belajar.

Faktor-faktor eksternal yang memengaruhi keaktifan belajar peserta didik kelas III SDN Ngujung 2 tahun ajaran 2017/2018 adalah faktor non sosial yaitu tempat dan fasilitas serta faktor sosial yaitu guru dan teman sebaya. Tempat, fasilitas, dan guru menjadi faktor pendukung keaktifan belajar peserta didik. Sedangkan teman sebaya dapat menjadi faktor pendukung sekaligus penghambat keaktifan belajar peserta didik. 
Saran-saran yang dapat diberikan, sebaiknya guru dapat mengarahkan energi peserta didik untuk hal yang positif, sehingga tidak merasa kelelahan saat belajar. Selain guru, Sekolah hendaknya melengkapi fasilitas belajar sehingga dapat membantu keaktifan belajar peserta didik dengan baik. Fasilitas tersebut nantinya dapat menunjang peserta didik untuk lebih aktif belajar seperti melengkapi buku perpustakaan, keadaan ruang kelas yang nyaman, dan pengaturan ruang kelas.

\section{DAFTAR PUSTAKA}

[1] N. Budiana and A. Mumpuni, "Pengembangan Materi Ajar Berbicara Berbasis Web untuk Meningkatkan Keterampilan Berbicara Siswa Kelas XI di SMA," Semantiks, pp. 644-655, 2019 ,

[Online].

Available: https://jurnal.uns.ac.id/prosidingsemantiks/article/view/39412/26016.

[2] N. Wibowo, "Upaya Peningkatan Keaktifan Siswa Melalui Pembelajaran Berdasarkan Gaya Belajar Di Smk Negeri 1 Saptosari," Elinvo (Electronics, Informatics, and Vocational Education), vol. 1, no. 2, pp. 128-139, 2016, [Online]. Available: https://journal.uny.ac.id/index.php/elinvo/article/view/10621.

[3] S. Suarni, "Meningkatkan Kaktifan Belajar Siswa Pada Kompenensi Dasar Organisasi Pelajaran PKN Melalui Pendekatan Pembelajaran Pakem untuk Kelas IV SD Negeri 064988 Medan Johor T.A 2014/2015," Journal of Physics and Science Learning, vol. 01, no. 2, pp. 130-140, 2017, [Online]. Available: https://jurnal.uisu.ac.id/index.php/PASCAL/article/view/347.

[4] U. M. Usman, Upaya Optimalisasi KBM. Bandung: Remaja Rosdakarya, 2004.

[5] A. Hariandi and A. Cahyani, "Meningkatkan Keaktifan Belajar Siswa Menggunakan Pendekatan Inkuiri Di Sekolah Dasar," Jurnal Gentala Pendidikan Dasar, vol. 3, no. 2, pp. 353-371, 2018, [Online]. Available: https://journal.uny.ac.id/index.php/elinvo/article/view/10621.

[6] M. Syah, "Psikologi Pendidikan dengan pendekatan Baru," Remaja Rosda Karya. Bandung, 2010.

[7] M. Maradona, "Faktor- faktor yang Mempengaruhi Keaktifan Belajar Siswa Kelas IV B SD," Jurnal Pendidikan Guru Sekolah Dasar, vol. 17, no. 5, 2016.

[8] L. J. Moleong, "Metode Penelitian Kualitatif (Issue Metode Penelitian Kualitatif)," Fip.Um.Ac.Id, vol. 2. p. 157, 2007, [Online]. Available: http://fip.um.ac.id/wpcontent/uploads/2015/12/3_Metpen-Kualitatif.pdf.

[9] Sugiyono, Metode penelitian pendidikan. Bandung, 2013.

[10] Sumadi Suryabrata, Psikologi Pendidikan. Jakarta: Rajawali Pers, 2014.

[11] Slameto, "Belajar dan Faktor-faktor yang Mempengaruhinya." Rineka Cipta, Jakarta, 2010.

[12] U. Mabruroh, D. Sunarsih, and A. Mumpuni, "Analisis Kesulitan Belajar Muatan Matematika Kelas IV SD Tahfidzul Qur'an Darul Abror,” Jurnal Ilmiah KONTEKSTUAL, vol. 2, no. 01, pp. 58-68, 2020, [Online]. Available: http://jurnal.umus.ac.id/index.php/kontekstual/article/view/250.

[13] F. S. Wahid, M. A. Purnomo, and S. M. Ulya, "Analisis Peran Guru Dalam Pemanfaatan Lingkungan Sekolah Terhadap Kreativitas Belajar Siswa," Jurnal Ilmiah KONTEKSTUAL, vol. 2, no. 01, pp. 38-42, 2020, [Online]. Available: http://jurnal.umus.ac.id/index.php/kontekstual/article/view/247.

[14] O. Ariyawong and T. Phongsatha, "The Student's Self-Designed Learning Activities Influencing Their Learning Achievement: A Case Study of an English Tutorial Center in Krabi," Jurnal Vision, vol. 4, no. 2, pp. 28-44, 2017, [Online]. Available: https://www.proquest.com/scholarly-journals/student-s-self-designed-learningactivities/docview/2384088988/se-2?accountid=201395. 
[15] F. Fembriani, "Model Jigsaw untuk Meningkatkan Aktivitas dan Hasil Belajar Matakuliah Konsep Dasar IPA SD," Jurnal Ilmiah KONTEKSTUAL, vol. 1, no. 02, pp. 66-73, 2020, [Online]. Available: http://jurnal.umus.ac.id/index.php/kontekstual/article/view/164.

[16] M. Toharudin and A. Rukyat, "Model Pendampingan Belajar Pada Anak Keluarga TKW Di SD Negeri Wanacala 02 Brebes," Jurnal Ilmiah KONTEKSTUAL, vol. 2, no. 01, pp. 50-56, 2020, [Online].

http://jurnal.umus.ac.id/index.php/kontekstual/article/view/249. 